\title{
Strategi City Branding Jakarta Sebagai Ibukota Multikultural (Studi Deskriptif Kualitatif Dinas Pariwisata Dan Kebudayaan DKI Jakarta)
}

City Branding Strategy of Jakarta as a Multicultural Capital (Qualitative Descriptive Study at the Department of Tourism and Culture in DKI Jakarta Province)

\author{
Rosanah \\ Program Studi Ilmu Komunikasi Fakultas Ilmu Sosial dan Ilmu Politik \\ Universitas Nasional \\ Alamat: Jl. Sawo Manila, Pasar Minggu, Kota Jakarta Selatan 12520 \\ rosanahalie@yahoo.com.
}

Dikirim: 4 Mei 2020, Direvisi: 12 Mei 2020, Diterima: 16 Juni 2020, Terbit: 18 Juni 2020

Sitasi: Rosanah. (2020). Strategi City Branding Jakarta sebagai Ibukota Multikultural (Studi Deskriptif Kulaitatif Dinas Pariwisata dan Kebudayaan DKI Jakarta). PRoMEDIA. Volume 6 (1), Juni 2020, hal 123- hal 154

\begin{abstract}
Jakarta as the nation's capital that reflects "miniature Indonesia" with a diversity of cultures, ethnicities and religions is one in the frame of "Unity in Diversity". Based on the Vision and Mission of the DKI Jakarta Governor for the 2017-2022 period, the DKI Jakarta Tourism and Culture Office through the Domestic Marketing Promotion Section will conduct a City Branding in order to realize Jakarta as a Multicultural Capital for all various groups and communities in the capital. City Branding is a marketing strategy in order to build a city's identity. Imaging the city requires each region to create an image of a particular city that shapes the character of the city that is intended to shape and enhance tourism and cultural potential. Multiculturalism with its various uniqueness and the slogan "Enjoy Jakarta" as the identity of the city of Jakarta is a strategy to package as city image of Jakarta as a tourist and cultural destination with international standards. This study aims to describe the activities of the Department Tourism and
\end{abstract}


Culture of DKI Jakarta Province in conducting the City Branding of Jakarta as the Multicultural Capital. This research uses descriptive qualitative with documentation study and interviews as a primary data source. The results of research on City Branding Jakarta as the Multicultural Capital are carried out through the Integrated Marketing Communication strategy, namely: Promotion, Advertising, Direct Selling, Personal Selling and Public Relations. Among them through innovative local cultural collaborative events and various international scale events, infrastructure development of the capital and tourist destinations, as well as the use of various social media platforms and online media. The implementation of City Branding of the Jakarta Tourism and Culture Office also establishes cooperation and involves various parties such as local communities, investors and stakeholders such as synergy with the "Jakarta Tourism" community, through exploration, elaboration and collaboration of various tourism and cultural potentials in realizing Jakarta not only as a city transit but can increase the number of domestic and foreign tourists. The parameters of success of the City Branding strategy can be seen among others based on an increase in the number of tourists and accommodation, The Number of Tourism, Length of Stay (LoS), Money Circulation, and various awards won by the Department of Tourism and Culture and the Governor of DKI Jakarta Province".

\title{
Keywords: Communication Strategy, City Branding, Multicultural Capital
}

\begin{abstract}
Abstraksi
Jakarta sebagai Ibukota Negara yang merefleksikan "miniatur Indonesia", dimana keberagaman budaya, suku, etnis, dan agama kumpul menjadi satu dalam bingkai "Bhineka Tunggal Ika". Mengacu pada Visi dan Misi Gubernur DKI Jakarta Periode 2017-2022, Dinas Pariwisata dan Kebudayaan DKI Jakarta melalui Bidang Destinasi Pemasaran Seksi Promosi
\end{abstract}


Dalam Negeri melakukan City Branding dalam rangka mewujudkan Jakarta sebagai Ibukota Multikultural yang merangkul seluruh golongan dan komunitas yang ada di ibukota. City branding adalah strategi pemasaran dalam rangka membangun identitas sebuah kota. City branding menuntut setiap daerah untuk berlomba menciptakan citra tertentu sehingga terbentuklah city image yang menjadi karakter sebuah kota yang bertujuan untuk membentuk dan meningkatkan potensi wisata dan budaya. Multikulturalisme dengan berbagai keunikannya dan slogan "Enjoy Jakarta" sebagai identitas kota Jakarta merupakan strategi Packaging sebuah brand atau City Image Ibukota Jakarta sebagai tujuan wisata dan budaya dengan standar Internasional". Penelitian ini bertujuan untuk mendeskripsikan aktivitas Dinas Pariwisata dan Kebudayaan Provinsi DKI Jakarta dalam melakukan City Branding Jakarta sebagai Ibukota Multikultural. Penelitian ini menggunakan pendekatan deskriptif kualitatif dengan studi dokumentasi serta wawancara sebagai sumber data primer. Berdasarkan hasil penelitian, City Branding Jakarta sebagai Ibukota Multikultural dilakukan melalui strategi Integrated Marketing Communication, yaitu: Promotion, Advertising, Direct Selling, Personal Selling dan Public Relations. Diantaranya melalui event kolaboratif budaya lokal yang Inovatif serta berbagai event skala Internasional, pembangunan infrastruktur ibukota dan destinasi wisata, serta pemanfaatan berbagai platform media online dan media sosial. Implementasi City Branding Dinas Pariwisata dan Kebudayaan DKI Jakarta juga menjalin kerjasama dan melibatkan berbagai pihak seperti masyarakat lokal, investor dan stakeholders seperti sinergitas dengan komunitas "Jakarta Tourism", melalui ekplorasi, elaborasi dan kolaborasi berbagai potensi wisata dan budaya dalam rangka mewujudkan Jakarta bukan hanya sebagai kota transit semata akan tetapi dapat meningkatkan jumlah wisatawan dalam dan luar negeri. Parameter keberhasilan dari strategi City Branding diantaranya dapat dilihat berdasarkan adanya peningkatan jumlah wisatawan dan akomodasi, The Number of Tourism, Length of Stay (LoS), Peredaran uang, serta berbagai 
penghargaan yang diraih Dinas Pariwisata dan Kebudayaan dan Gubernur Provinsi DKI Jakarta.

\section{Kata Kunci: Strategi Komunikasi, City Branding, Ibukota Multikultural.}

\section{PENDAHULUAN}

Jakarta sebagai Ibukota Negara yang merefleksikan "miniatur Indonesia", dimana keberagaman budaya, suku, etnis, dan agama kumpul menjadi satu dalam bingkai "Bhineka Tunggal Ika". Kota Jakarta, sejak kelahirannya pada 22 Juni 1527, merupakan salah satu kota besar di Indonesia yang mencerminkan multikultural yang tidak mengenal relevansi batas antara asli dan pendatang. Karena itulah, sedari dahulu Jakarta menjadi kota yang memberikan kemudahan aksebilitas dan kenyamanan untuk dihuni oleh semua orang Indonesia. Hal ini didukung pula oleh karakteristik dari masyarakat asli Jakarta yang sangat opensif dan "welcome" terhadap siapapun dari berbagai daerah di Indonesia yang datang ke Jakarta. Sejarah mencatat bahwa Jakarta adalah kota global dimana warga asli Jakarta (betawi) mampu menyerap dan menerima beragam budaya dunia yang masuk dengan ramah sehingga terjadi persenyawaan kebudayaan.

Mengacu pada visi Pemerintah DKI Jakarta (www.ppid.jakarta.go.id, diakses 22 November 2019) Periode 2017-2022, yang berbunyi: "Jakarta kota maju, lestari dan berbudaya yang warganya terlibat dalam mewujudkan 
keberadaban, keadilan dan kesejahteraan bagi semua". Adapun salah satu misinya, yaitu: "menjadikan Jakarta ibukota yang dinamis sebagai simpul kemajuan Indonesia yang bercirikan keadilan, kebangsaan dan kebhinekaan”.

Dinas Pariwisata dan Kebudayaan (Disparbud) DKI Jakarta melalui Bidang Destinasi Pemasaran Seksi Promosi Dalam Negeri melakukan City Branding dalam rangka mewujudkan Jakarta sebagai Ibukota Multikultural yang merangkul seluruh golongan dan komunitas yang ada di ibukota. Dinparbud DKI Jakarta sangat memahami keberagaman budaya yang ada. Menyadari akan pentingnya penguatan kembali bahwa Jakarta merupakan Ibukota Multikultural, maka berbagai upaya dilakukan salah satunya melalui strategi City Branding, sebagai salah satu bagian penting yang tidak dapat terpisahkan dari strategi pemasaran terpadu atau disebut dengan Integrated Marketing Communication dalam upaya untuk membangun dan menciptakan city image Jakarta sehingga secara tidak langsung akan meningkatkan laju pertumbuhan ekonomi dan masyarakat Ibukota.

Upaya mewujudkan dan mengembangkan potensi pariwisata dan budaya di Jakarta, maka dibutuhkan strategi yang tepat dan perencanaan yang matang. City branding adalah strategi pemasaran kota dalam rangka membangun identitas sebuah kota. City branding menuntut setiap daerah untuk berlomba menciptakan citra tertentu sehingga terbentuklah city image yang 
menjadi karakter sebuah kota yang dapat membentuk dan meningkatkan potensi wisata dan budayanya. Slogan "Enjoy Jakarta" merupakan tagline of City Branding yang telah disosialisasikan oleh Dinparbud DKI Jakarta sejak 11 Maret 2005 lalu yang bertujuan untuk untuk meningkatkan jumlah kunjungan wisatawan asing atau mancanegara. Deskripsi inilah yang kemudian melatarbelakangi dan menjadi dasar pemikiran dari penelitian ini. Penelitian ini berfokus pada analisis strategi City Branding Jakarta sebagai Ibukota Multikultural yang dilakukan oleh Dinas Pariwisata dan Kebudayaan DKI Jakarta selama periode tahun 2018 dan 2019, dengan menggunakan metode penelitian deskriptif kualitatif. Secara umum, rumusan penelitian ini adalah: "Bagaimana strategi City Branding yang dilakukan oleh Dinas Pariwisata dan Kebudayaan DKI Jakarta dalam membranding Jakarta sebagai Ibukota Multikultural?” Adapun tujuan dari penelitian ini adalah untuk mengetahui bagaimana strategi City Branding Jakarta sebagai Ibukota multikultal studi kasus pada Dinas Pariwisata dan Kebudayaan DKI Jakarta.

\section{TINJAUAN PUSTAKA}

\section{A. Penelitian Terdahulu}

Penelitian-penelitian terdahulu yang pernah dilakukan terutama berkaitan dengan strategi City Branding Kota Jakarta dapat dilacak antara lain dari penelitian City Branding Kota Jakarta yang dilakukan oleh Vience Mutiara Rumata, 
Universitas Padjadjaran tahun 2006 dengan judul "Strategi City Branding Kota Jakarta; Studi Kasus Mengenai Branding Pariwisata Kota Jakarta Melalui Slogan "Enjoy Jakarta" Berdasarkan Platform Branding Strategy Landor Sebagai Branding Consultant And Designer Worlwide”. Hasil Penelitian menunjukkan bahwa Jakarta, ibu kota Indonesia ini perlu mendapat perhatian khusus perihal upaya memiliki citra yang mampu bersaing di tengah gempuran negara-negara tetangganya seperti Singapura, Malaysia ataupun Thailand. Dinas Pariwisata DKI Jakarta sudah memiliki dasar pemikiran yang sama sehingga lahirlah "Enjoy Jakarta" sejak 2006 silam. Namun, eksekusi branding yang dilakukannya tidak tepat dan kurang efektif. Pemerintah Propinsi masih menganggap "Enjoy Jakarta" hanya sebagai slogan dan logo, tanpa ada "ruh" yang menghidupi brand tersebut

\section{B. Definisi Komunikasi}

Everett M. Roger dalam Changara (2014:35) mendefinisikan komunikasi sebagai proses dimana sebuah ide dialihkan dari sumber kepada satu penerima atau lebih yang bertujuan mengubah tingkah laku mereka. Definisi ini kemudian dikembangkan oleh Lauwerence D. Kincaid dalam Changara (2014:36) sehingga melahirkan satu definisi yang lebih maju dengan menyatakan bahwa komunikasi adalah proses dimana dua orang atau lebih membentuk atau melakukan pertukaran 
informasi dengan satu sama lainnya, yang pada gilirannya akan tiba pada saling pengertian yang mendalam.

Pengertian komunikasi secara umum adalah proses pengiriman dan penerimaan informasi atau pesan antara dua individu atau lebih dengan efektif sehingga bisa dipahami dengan mudah. Komunikasi terjadi saat pesan disampaikan oleh pengirim pesan dan diterima oleh penerima pesan. Dalam komunikasi terdapat unsur-unsur komunikasi yang harus dipenuhi. Adapun komponen komunikasi meliputi komunikator atau pengirim pesan, komunikan atau penerima pesan, media atau perantara, pesan atau informasi, efek yang ditimbulkan serta umpan balik.

\section{Komunikasi Pemasaran Terintegrasi}

Menurut Kotler dan Keller (2012:498), komunikasi pemasaran adalah sarana yang digunakan perusahaan dalam upaya untuk menginformasikan, membujuk, dan mengingatkan konsumen baik secara langsung maupun tidak langsung tentang produk dan merek yang mereka jual.

Munculnya berbagai inovasi pada piranti komunikasi, pesan dan khalayak memaksa perusahaan menoleh pada komunikasi pemasaran terintegrasi (Integrated Marketing Communications) yaitu menyatukan perencanaan, tindakan dan koordinasi pada semua wilayah komunikasi pemasaran dan juga memahami konsumen menyangkut apa sesungguhnya tanggapan konsumen. (Agus Hermawan, 2012:52). Menurut Kotler dan Amstrong 
(2008:116), terdapat lima bauran komunikasi pemasaran terintegrasi, yaitu sebagai berikut:

a. Iklan (Advertising) adalah komunikasi persuasif yang bertujuan untuk menarik kesadaran, menanamkan informasi, mengembangkan sikap, atau mengharapkan adanya suatu tindakan yang menguntungkan bagi pengiklan.

Promosi Penjualan (Sales Promotion) merupakan upaya pemasaran yang bersifat media dan non-media untuk merangsang coba-coba dari konsumen, meningkatk permintaan dari konsumen atau untuk memperbaiki kualitas produk. Upaya pemasaran melalui promosi penjualan ini dilakukan dalam jangka pendek.

b. Hubungan Masyarakat (Public Relations) yaitu membangun hubungan baik dengan berbagai kalangan untuk mendapatkan publisitas sesuai yang diinginkan, membangun citra perusahaan yang baik, dan menangani atau menghadapi rumor, berita dan kejadian tidak menyenangkan.

c. Penjualan secara Pribadi (Personal Selling) adalah Interaksi langsung yang terjadi dengan konsumen bertujuan untuk menginformasikan suatu produk sekaligus membujuk secara langsung untuk membeli.

d. Pemasaran Langsung (Direct Marketing) yaitu hubungan langsung dengan konsumen individual yang ditargetkan secara cermat untuk memperoleh respon segera dan membangun hubungan pelanggan yang langgeng. 


\section{Strategi Komunikasi Pemasaran}

Strategi pada hakekatnya adalah perencanaan dan manajemen untuk mencapai suatu tujuan. Marthin-Anerson (1968) dalam Changara (2014:64) merumuskan strategi sebagai seni yang melibatkan kemampuan inteligensia/ pikiran untuk membawa semua sumber daya yang tersedia dalam mencapai tujuan dengan memperoleh keuntungan secara maksimal dan efisien.

Terkait dengan hal ini, Roger (1982) memberikan batasan pengertian tentang strategi komunikasi sebagai suatu rancangan yang dibuat untuk mengubah tingkah laku manusia dalam skala yang lebih besar melalui transfer ide-ide baru. Seorang pakar perencanaan komunikasi, Middleton (1980) dalam Changara (2014:64) membuat definisi dengan menyatakan bahwa "Strategi komunikasi adalah kombinasi yang terbaik dari semua elemen komunikasi mulai dari komunikator, pesan, saluran (media), penerima pesan sampai kepada pengaruh (efek) yang dirancang untuk mencapai tujuan komunikasi yang optimal.

\section{Gambar 1. Sistem Komunikasi Pemasaran}

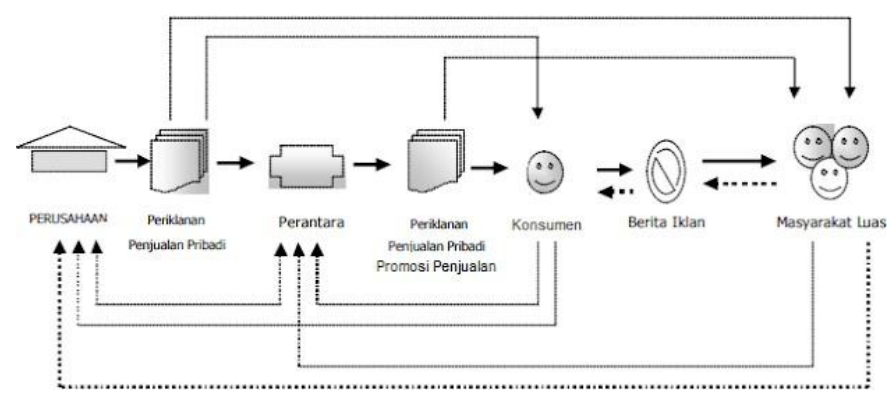


Para pemasar berkomunikasi dengan perantara, konsumen, dan berbagai kelompok masyarakat. Kemudian perantara berkomunikasi kepada konsumennya dan masyarakat. Konsumen melakukan lisan dengan konsumen lain dan dengan kelompok masyarakat lain. Sementara itu, setiap kelompok memberikan umpan balik kepada setiap kelompok-kelompok yang lain. Sulaksana (2007:33) menuliskan proses implementasi komunikasi pemasaran adalah sebagai berikut:

a. Sumber (source), yaitu pesan yang menentukan tujuan komunikasi dan menetapkan sasaran komunikasi. Pemasar membuat tujuan kampanye iklan dan promosi dengan mengarahkan kampanye itu pada segment sasaran tertentu.

b. Proses Enconding, yaitu penyandian tujuan menjadi sebuah pesan. Agensi iklan merancang pesan yang disandikan dalam bentuk iklan. Pesan disandikan wiraniaga dalam bentuk presentasi penjualan.

Pengiriman (Tranmission), yaitu pengiriman pesan melalui media agar dapat menjangkau audiens sasaran. Penyebaran komunikasi pemasaran bisa lewat media massa, komunikasi getok tular dari wiraniaga, atau selebaran direct-mail yang dikirimkan pada sasaran.

a. Proses Decoding oleh penerima agar pesan dapat dipahami dua pertanyaan utama adalah apakah konsumen menafsirkan pesan seperti yang di inginkan pengiklan, dan apakah pesan berdampak positif pada sikap dan perilaku konsumen. 
b. Umpan balik (feedback) atas efektivitas komunikasi pemasaran kepada sumber.

Strategi komunikasi pemasaran adalah paduan perencanaan komunikasi agar dapat mencapai tujuan yang sudah ditetapkan. Pada marketing communication, strateginya adalah paduan panduan perencanaan komunikasi dengan manajemen komunikasi pemasaran. Strategi ini dikenal juga sebagai komunikasi pemasaran terintegrasi. Komunikasi pemasaran terpadu sendiri ialah suatu strategi yang ditujukan pada konsumen. Penyusunan strategi ini akan memerlukan pemikiran yang memperhitungkan aneka faktor pendukung serta penghambat. Harus pula diperhatikan komponen dalam marketing communication yang bisa mendukung proses nantinya.

\section{E. Strategi City Branding}

City Branding adalah upaya membangun identitas sebuah kota. Identitas adalah sebuah kontruksi, sebuah konsekuensi dari sebuah proses interaksi antar manusia, institusi dan praktis dalam kehidupan sosial. Berbicara mengenai City Branding maka tidak akan terlepas dari pembicaraan mengenai merek, karena City Branding identik sebagai bagian dari konsep merek itu sendiri. Kegiatan City Branding ini menuntut setiap daerah berlomba menciptakan citra tertentu dibenak masyarakat luas dalam merepresentasikan karakter kota. Citra kota memiliki kekuatan dalam membentuk merek sebuah kota, bahkan 
mempengaruhi kota itu sendiri. Merek yang melekat pada kota sangat bergantung pada identitas kota.

City Branding merupakan upaya strategi dari suatu kota untuk membuat positioning yang kuat di regional maupun global. Dengan adanya City Branding dapat membentuk identitas kota yang berguna untuk memasarkan segala aktivitas kegiatan, saran serta budaya yang ada di kota tersebut. City Branding berkaitan juga dengan tata rencana kota yang dapat dijadikan sebuah strategi dari suatu kota untuk membuat positioning yang kuat di dalam target pemasaran, seperti halnya positioning sebuah produk atau jasa.

Kavaratzis dalam Primasari (2014:6) menjelaskan bahwa

"City Branding dipahami sebagai sarana untuk mencapai keunggulan kompetitif dalam rangka untuk meningkatkan investasi dari pariwisata, dan juga sebagai pencapaian pembangunan masyarakat. Memperkuat identitas lokal dan identitas warga dengan kota dan mengaktifkan semua kalangan sosial demi menghindari pengucilan dan kerusuhan sosial"

Mem-branding kota memerlukan beberapa faktor pendukung seperti bagaimana konsep dan tujuan brand itu sendiri yang dibuat oleh pemerintah kota setempat, kemudian bagaimana cara memasarkan city brand tersebut agar sebuah kota itu bisa menjadi obyek yang layak untuk dipasarkan. Dari hal tersebut arti penting dari komunikasi pemasaran akan menjadi acuan pemerintah kota dalam menentukan tujuannya 
dalam melakukan city branding. Komunikasi erat kaitannya dengan media dan media sekarang sudah menjadi bagian dari kehidupan sehari-hari. Sehingga dalam menjalankan suatu pemasaran maka diperlukan media sebagai alat komunikasi efektif untuk menyampaikan pesan untuk target yang dituju. Jadi pemilihan media harus dipertimbangkan oleh pemerintah kota dalam memasarkan kotanya melalui sebuah city image and brand.

Simon Anholt (2007) mendefinisikan city branding sebagai bagian dari kajian ilmu komunikasi terutama sebagai fungsi Public Relations yaitu dengan mengartikan city branding sebagai manajemen citra suatu destinasi melalui inovasi strategis serta koordinasi ekonomi, komersial, sosial, kultural, dan peraturan pemerintah. Pengertian ini diperkuat dengan pendapat lain yang dicetuskan oleh Kavaratzis (2008:8) yang mengungkapkan bahwa city branding umumnya memfokuskan pada pengelolaan citra, tepatnya apa dan bagaimana citra itu dibentuk serta aspek komunikasi yang dilakukan dalam proses pengelolaan citra. City branding juga merupakan tugas dan kolaborasi dari semua pihak (Stakeholders) yang terkait dengan kota tersebut. Tanggung jawab kesukseskan city branding terdapat diseluruh public internal kota, baik pemerintah kota, swasta, pengusaha, Interest Group dan masyarakat kota. Dalam City Branding, yang diutamakan adalah dengan memfungsikan seluruh potensi kota agar bernilai dan fungsional. 


\section{F. Teori Integrasi Informasi dan Perubahan Sikap}

Tugas Public Relations yaitu mempengaruhi sikap publik dengan memberikan informasi tertentu. Teori Integrasi Informasi dan Perubahan Sikap berpandangan bahwa Informasi berperan sebagai alat untuk mengubah sikap. Teori ini mengasumsikan individu sebagai manusia yang mempunyai kemampuan mengolah informasi yang meliputi; proses mengumpulkan dan mengorganisasi informasi tentang sesuatu hal dan memengaruhi sikapnya sesuai konsep yang diperolehnya saat mengelola informasi itu. Berbagai jenis informasi dijadikan bahan pemikirannya dan diolah sebelum mengambil keputusan atau sikap tertentu.

Menurut Heath (2005) dalam Kriyantono (2014: 301) teori ini sangat sederhana, yaitu menjelaskan bahwa individu membentuk sikapnya dengan cara memadukan atau mengintegrasikan informasi atau hal-hal yang positif maupun negatif. Informasi memegang peranan penting dalam pembentukan sikap. Akumulasi informasi yang diserap seseorang dapat menimbulkan dampak: a) informasi dapat merubah derajat kepercayaan seseorang terhadap suatu objek; b) informasi dapat mengubah kredibilitas kepercayaan seseorang yang sudah dimiliki seseorang; dan c) informasi dapat menambah kepercayaan baru yang telah ada dalam struktur sikap. Informasi yang didapat seseorang dari proses interaksi akan membentuk 
pengetahuan seseorang tertentu tentang suatu objek, dan jenis pengetahuan ini akan memengaruhi pembentukan sikap.

Heath (2005) dan Littlejhon \& Fos (2005) mengatakan bahwa kecenderungan sikap seseorang bersifat konsisten dan sulit berubah. Ada beberapa faktor penyebabnya, yaitu: pertama, sikap terhadap suatu objek yaitu kumpulan atau akumulasi pengetahuan dan informasi tentang objek tersebut dari proses interaksi dalam kurun waktu tertentu. Informasi memperoleh pengetahuan itu dari berbagai sumber, interpersonal dan media massa. Terpaan dari media massa yang bersifat terus menerus (ubiquity) dan diulangulang membuat akumulasi pengetahuan semakin tinggi. Jika informasi yang diterima individu lebih banyak menonjolkan satu aspek tertentu dari suatu objek, maka pengetahuan akan terakumulasi banyak pada satu aspek itu. Kedua, sikap mencerminkan kesukaan dan keyakinan (kepercayaan) individu yang telah mengalami proses pembentukan melalui pengetahuan dan pengalaman. Informasi atau pengetahuan yang baru diperoleh cenderung bersifat meneguhkan atau menguatkan pengetahuan atau sikap yang telah ada. Hal ini juga dipengaruhi oleh alasan ketiga, yaitu: individu memiliki selektivitas dalam memperhatikan objek (selective attention), memersepsikannya (selective perception), dan mengingatnya (selective retention), individu cenderung memperhatikan, memersepsikan, dan mengingat informasi sesuai dengan keyakinannya, kesukaannya, dan kepentingannya. Dalam konteks ini, keyakinan, kesukaan dan 
kepentingan tersebut dapat menolak informasi baru. (Kriyantono, 2014:301).

Kecenderungan sikap untuk konsisten dan sulit berubah tidaklah bersifat mutlak. Artinya, masih dimungkinkan atau masih ada peluang adanya perubahan sikap. Hal ini mengacu pada pendapat Heath (2005:418), bahwa "teori informasi integration menekankan pada peran penting informasi dalam memengaruhi sikap atau kecenderungan untuk berperilaku. Jadi sikap masih bisa berubah karena terpaan informasi baru.

Public Relations dapat menerapkan teori ini dalam program kampanyenya untuk mengubah perilaku atau sikap publik. Pesan kampanye dapat didesain untuk mengubah arah informasi negatif atau positif, atau menyediakan informasi untuk menambah kepercayaan baru yang terkait dengan topik atau organisasi. Penyebaran informasi harus dilakukan secara kontinyu sehingga menghasilkan efek terpaan yang sangat tinggi. Terpaan yang tinggi secara bertahap dapat memperteguh kognisi dan kepercayaan publik. Penyebaran informasi dapat dilakukan melalui berbagai media komunikasi public relations.

\section{G. Multikulturalisme dan Potensi Wisata}

Akar kata multikulturalisme adalah kebudayaan. Kata "multi" mengandung arti beraneka ragam. "Kultural" adalah istilah lain dari budaya. Masyarakat Ibukota Jakarta adalah masyarakat multikultural. Beragam budaya menjadi ekspresi 
identitas masyarakat yang satu sama lain berbeda. Pengertian "multikultural" terlihat dari adanya perbedaan budaya, suku, agama, ras, etnis, bahasa, dan sebagainya dalam suatu masyarakat luas. Jakarta sebagai ibukota Negara Indonesia sejak dahulu kala merupakan "cerminan nusantara" dengan semboyan Bhinneka Tunggal Ika sebenarnya sudah mengandung makna keberagaman yang terdiri dari berbagai ragam kultur atau budaya dan tercatat dalam sejarah sebagai masyarakat multikultural. Menurut Choirul Mahfud (2011:xix), secara etimologis multikulturalisme dibentuk dari kata multi (banyak), kultur (budaya), dan isme (aliran/paham). Secara hakiki, dalam kata itu terkandung pengakuan akan martabat manusia yang hidup dalam komunitas dengan kebudayaannya masing-masing yang unik. Dengan demikian, setiap individu merasa dihargai sekaligus merasa bertanggungjawab untuk hidup bersama komunitasnya. Dari karakteristik ini, dapat dikembangkan pemahaman mengenai multikulturalisme yaitu sebagai sebuah paham tentang kultur yang beragam. Dalam situasi keragaman kultur ini meniscayakan adanya pemahaman, saling pengertian, toleransi, penghargaan, penghormatan, kerjasama dan lainnya agar tercipta suatu kehidupan yang damai dan sejahtera serta terhindar dari konflik dan kekerasan.

Pengertian di atas maka dapat ditarik kesimpulan bahwa mutikulturalisme merupakan konsep sebuah komunitas yang mengakui adanya keberagaman, perbedaan, dan kemajemukan 
budaya baik ras, suku, etnis dan agama. Konsep yang memberikan pemahaman bahwa sebuah kota yang terdiri dari masyarakat yang plural atau majemuk adalah kota yang dipenuh dengan budaya-budaya yang beragam. Kota yang muktikultur adalah kota yang terdiri dari kelompok-kelompok etnik dan budaya yang ada dapat hidup berdampingan secara damai dalam prinsip co-existence yang ditandai dengan kesediaan untuk menghormati budaya lain.

Provinsi DKI Jakarta sangat berbeda dengan provinsi lain di Indonesia. Sebagai Ibukota Negara, Jakarta sangat heterogen, semua suku, golongan dan agama terwakili berada di dalamnya. Jakarta dikatakan sebagai kota multikultural apabila siap melayani dan memfasilitasi seluruh warganya yang berasal dari etnis dan suku yang beragam untuk mengekspresikan multikultural tanpa menggeser budaya lokal Jakarta. Multikulturalisme adalah keunikan dan menjadi daya tarik tersendiri bagi sebuah kota yang dapat dijadikan sebagai potensi wisata berkonsep budaya yang terafiliasi dalam berbagai destinasi wisata dan ruang ekspresi bagi setiap komunitas budaya untuk mengeksplorasi keunikannya. Keunikan, kesetaraan dan keberagaman menawarkan sebuah kenyamanan yang dapat mendorong masyarakat di seluruh Indonesia tertarik untuk datang dan berwisata ke sebuah kota budaya yang multikultural.

Vitasurya, dkk dalam Sugiarto 2018:46 mengatakan bahwa multikulturalisme atau keberagaman budaya merupakan kearifan 
lokal, yaitu: seperangkat pengetahuan dan praktik-praktik baik yang berasal dari generasi-generasi sebelumnya maupun dari pengalaman berhubungan dengan lingkungan dan masyarakat lainnya milik suatu komunitas di suatu tempat, yang digunakan untuk menyelesaikan baik dan benar berbagai persoalan dan atau kesulitan yang dihadapi. Kearifan lokal berasal dari nilai-nilai adat istiadat, nilai-nilai keagamaan dan budaya lokal yang secara alami terbentuk dalam suatu kelompok masyarakat untuk beradaptasi dengan lingkungan sekitar. Kearifan lokal menjadi suatu ciri khas masing-masing daerah yang berpotensi untuk mendukung pengembangan suatu daerah. Potensi budaya dan kearifan lokal dalam pengembangan pariwisata menjadi bagian dari produk kreativitas manusia yang memiliki nilai ekonomi. Salah satu upaya pengembangan pariwisata berbasis budaya dan kearifan lokal adalah pengemasan budaya lokal dalam bentuk festival seperti festival budaya Jakarta berkolaborasi dengan budaya daerah-daerah lainnya

\section{METODOLOGI PENELITIAN}

Penelitian deskriptif kualitatif ini hanyalah memaparkan situasi atau peristiwa. Penelitian ini tidak mencari atau menjelaskan hubungan, tidak menguji hipotesis atau membuat prediksi Sehingga penelitian hanya sekedar mengungkap fakta yang terjadi di lapangan. Penelitian ini dilaksanakan di dalam lingkup Dinas Pariwisata dan Kebudayaan DKI Jakarta. 
Narasumber penelitian ditentukan melalui teknik "purposive sampling", karena informan/narasumber sebagai data ditentukan berdasarkan anggapan atau pendapat peneliti sendiri, peneliti akan memilih informan yang dianggap paling tahu, sehingga mampu memberikan informasi yang cepat dan akurat. Pemilihan informan adalah bukan untuk mengeneralisasi akan tetapi hanya berdasar konteks unik informan yang diwawancara dengan berdasar pemilihan secara purposive. Informan yang menjadi sumber data primer antara lain:

1. Kepala Pelaksana Tugas (Plt) Kepala Dinas Pariwisata dan Kebudayaan (Disparbud) Provinsi DKI Jakarta yaitu Bapak Asiantoro.

2. Bidang Destinasi dan Pemasaran Seksi Promosi dalam Negeri, yaitu Bapak Ihsan Ramadhan.

Informan dalam penelitian kualitatif tidak ditentukan jumlahnya akan tetapi yang terpenting adalah kedalaman informasi yang dapat diperoleh peneliti (Zizansky, et all 1992:233). Dalam penelitian ini menggunakan teknik pengumpulan data triangulasi sumber. Triangulasi sumber adalah peneliti menggunakan beberapa sumber untuk mengumpulkan data yang sama. Triangulasi sumber digunakan karena dalam penelitian ini, data diperoleh dari berbagai macam sumber yang berbeda sehingga dapat dipertanggungjawabkan kebenarannya. Peneliti juga melakukan studi dokumentasi dan kajian pustaka secara mendalam tentang berbagai informasi 
terkait strategi City Branding Jakarta yang dilakukan oleh Dinas Pariwisata dan Kebudayaan DKI Jakarta.

\section{PEMBAHASAN}

\section{A. Strategi Komunikasi Pemasaran Dinas Pariwisata dan Kebudayaan DKI Jakarta}

Strategi komunikasi pemasaran yang dilakukan oleh

Dinas Pariwisata dan Kebudayaan DKI Jakarta dalam melakukan city branding Jakarta sebagai ibukota multikultural dilakukan dengan melakukan kombinasi terbaik yang melibatkan semua elemen komunikasi sehingga tercapai tujuan komunikasi yang optimal, efektif dan efisien. Dinas Pariwisata dan Kebudayaan DKI Jakarta selaku sumber atau komunikator memahami pentingnya komunikasi yang efektif dalam berkomunikasi dan membina hubungan baik kepada seluruh stakeholders baik publik internal dalam ruang lingkup pemerintahan DKI Jakarta maupun masyarakat luas. Karena informasi positif yang disampaikan kepada seluruh stakeholders akan mudah tersebar secara estafet kepada masyarakat luas dan berbagai citra atau penilain positif dari masyarakat maka akan kembali kepada Disparbud. Proses implementasi yang dilakukan oleh Dinpasbud DKI Jakarta, meliputi:

a Dalam menjalankan strategi komunikasi pemasaran melalui city branding, Sumber source) meliputi Disparbud DKI Jakarta sampai kepada level Suku Dinas Pariwisata 
Walikotamadya menentukan tujuan setiap aktivitas yang dilakukan dan menetapkan target sasaran dari setiap program, kegiatan dan kampanye serta promosi yang dilakukan. Dalam hal ini, komunikator melipatkan seluruh publik internal di Pemerintahan DKI Jakarta terutama pernyataan-pernyataan Gubernur DKI Jakarta dan seluruh jajarannya.

Proses penyandian pesan dilakukan dengan mengemas (packaging) pesan semenarik dan sekreatif mungkin baik dalam bentuk tagline atau slogan, desain logo maupun dalam merancang dan memproduksi pesan promosi dan pemasaran, seperti "Enjoy Jakarta; Serahkan pada Ahlinye!", dan “Wisata Kreatif Jakarta”.

b. Media yang digunakan oleh Dinparbud DKI Jakarta dalam pelaksanaan City Branding adalah dengan memanfaatkan seluruh media promosi dan publikasi baik media lini bawah (above the line) seperti; berbagai event, festival atau karnaval budaya, maupun media lini bawah (below the line) seperti: bersinergi dengan berbagai media massa sebagai media support, media elektronik (televisi dan radio), media cetak dan pemanfaatan platform media baru (media online dan media sosial).

c. Penerima pesan atau target sasaran Dinparbud DKI Jakarta dalam implementasi strategi City Branding Jakarta sebagai Ibukota multikultural adalah seluruh stakeholders atau 
masyarakat umum di seluruh Indonesia termasuk juga wisatawan mancanegara.

d. Umpan balik (feedback) yang diharapkan dari upaya city branding yang dilakukan oleh Dinparbud DKI Jakarta adalah terciptanya sebuah city image Jakarta sebagai Ibukota Multikultural yang merangkul semua golongan dan komunitas serta memberi ruang ekspresi kepada seluruh budaya di Indonesia yang ada di Jakarta untuk berkolaborasi dan bersinergi dengan budaya lokal Jakarta.

e. Disparbud DKI Jakarta dalam menjalankan strategi komunikasi pemasaran dimulai dengan melakukan perencanaan komunikasi agar sesuai dengan tujuan yang ingin dicapai. Pada tahap perencanaan, maka rujukan utama adalah melakukan singkronisasi berbagai program promosi dan pemasaran dengan visi dan misi Pemerintah DKI Jakarta dan Rencana Strategis Jangka Panjang dan Jangka Pendek Dinas Pariwisata dan Kebudayaan DKI Jakarta. Pada tahap perencanaan juga dilakukan secara berlaka Focus Group Discussion (FGD) antara Dinparbud DKI Jakarta dengan Komunitas Bisnis dan Pariwisata di Jakarta seperti Komunitas "Jakarta Tourism", melalui ekplorasi, elaborasi dan kolaborasi berbagai potensi wisata dan budaya serta terkait Meeting, Incentive, Conference, Exhibition (MICE) dalam rangka mewujudkan Jakarta bukan hanya sebagai kota transit semata akan tetapi dapat meningkatkan jumlah wisatawan dalam dan luar negeri

Strategi pemasaran terintegrasi (integrated marketing 
communications) yang dilakukan oleh Dinparbud DKI Jakarta menyatukan perencanaan, tindakan dan koordinasi melalui lima bauran, sebagai berikut:

1. Iklan (Advertising) dengan melakukan pengemasan informasi dan pesan persuasif secara kreatif dan menarik dengan memanfaatkan semua media promosi dan publikasi yang dimiliki, tujuannya adalah mengajak seluruh masyarakat baik domestik maupun mancanegara untuk datang dan berkunjung ke Jakarta.

2. Promosi Penjualan (Sales Promotion) yang dilakukan oleh Dinparbud secara langsung sampai dengan level Suku Dinas Pariwisata tingkat Walikotamadya. Pada bauran ini, Dinparbud menjadikan Gubernur DKI Jakarta sebagai figure yang berperan penting dalam menyampaikan informasi dan pesan persuasive terkait dengan Jakarta sebagai Ibukota multikultural.

3. Hubungan Masyarakat (Public Relations) yaitu Dinparbud DKI membangun dan menjalin hubungan baik dengan seluruh stakeholders baik masyarakat, investor, bahkan media agar mendapatkan publisitas sesuai yang diinginkan, membangun citra perusahaan yang baik, dan menangani atau menghadapi rumor, berita dan kejadian tidak menyenangkan.

4. Penjualan secara Pribadi (Personal Selling) yang dilakukan Dinparbud DKI Jakarta melalui interaksi langsung dengan masyarakat bertujuan bertujuan untuk menginformasikan 
bahwa Jakarta merupakan Ibukota yang merangkul semua golongan dan komunitas.

5. Pemasaran Langsung (Direct Marketing) yaitu Dinparbud DKI Jakarta menjalin hubungan langsung dengan seluruh masyarakat Ibukota, melalui penyampaian pesan dan informasi selalu langsung melalui berbagai event, festival dan karnaval budaya yang diharapkan melalu event-event budaya tersebut maka Disparbud DKI Jakarta mendapat respon dan city image sebagai Ibukota Multikultural yang unik dan menarik

\section{B. City Branding Jakarta Sebagai Ibukota Multikultural}

Jakarta sebagai Ibukota Negara yang merefleksikan "miniatur Indonesia", dimana keberagaman budaya, suku, etnis, dan agama kumpul menjadi satu dalam bingkai "Bhineka Tunggal Ika". Karakteristik dari masyarakat asli Jakarta yang sangat opensif dan "welcome" terhadap siapapun dari berbagai daerah di Indonesia yang datang ke Jakarta. Jakarta sebagai Ibukota multikultural merupakan kota multikultural milik bersama yang melayani seluruh komunitas dan merangkul semua golongan. Konsep "Wajah Baru Jakarta" bermakna bahwa Jakarta kota metropolitan yang adil bagi warganya, yang merangkul semua golongan.

Provinsi DKI Jakarta sangat berbeda dengan provinisi lain, karena di Jakarta ini sangat heterogen, semua suku, golongan 
dan agama terwakili dan berada di dalamnya. Jakarta dikatakan sebagai kota multikultural apabila siap melayani dan memfasilitasi seluruh warganya yang berasal dari etnis dan suku yang beragam untuk mengekspresikan multikultural tanpa menggeser budaya lokal Jakarta. Keberagaman yang ada di Ibukota merupakan sebuah keunikan yang dapat dijadikan sebagai potensi wisata dan budaya bagi Ibukota sehingga dapat meningkatkan perekonomian masyarakat.

Pelaksana Tugas (Plt) Kepala Dinas Pariwisata dan Kebudayaan (Disparbud) Provinsi DKI Jakarta, Asiantoro mengatakan bahwa sesuai dengan visi dan misi Pemerintah DKI Jakarta untuk mengadakan berbagai event atau festival budaya sepanjang tahun dengan melibatkan masyarakat dan berbagai komunitas masyarakat dalam kegiatan festival dengan harapan melalui event dan festival budaya tersebut dapat meningkatkan laju pertumbuhan ekonomi dan bisnis di Jakarta. Dengan kata lain, sinergitas antara budaya dengan ekonomi bisnis.

Dinas Pariwisata dan Kebudayaan DKI Jakarta kian gencar memaksimalkan potensi destinasi wisata berbasis kawasan. Upaya untuk membangkitkan destinasi wisata yang dilakukan oleh Disparbud DKI Jakarta adalah sebagai berikut: 1) Penataan kawasan; 2) Revitaliasi tempat wisata, dan; 3) mengadakan event berskala Internasional. Berdasarkan informasi yang disampaikan oleh Kepala Bidang Informasi dan Pengembangan Dinas Pariwisata dan Kebudayan DKI Jakarta bahwa Jakarta 
memiliki destinasi wisata yang dibagi menjadi empat kawasan yakni Heritage, Nature, Urban, Youth, dan Culinary Destination. Heritage adalah destinasi yang kaya warisan budaya, seperti Kota Tua dan Taman Benyaim Sueb. Sedangkan Nature, adalah Pulau Seribu. Urban, misalnya Cikini dan Kemang Art Center serta Youth, yakni Pasar Kreatif Petodjo Enclek. Yang terakhir adalah Culinary yakni Jalan Sabang.

Berdasarkan analisis perspektif teori integritas informasi dan perubahan sikap, Dinparbud DKI Jakarta melakukan strategi city branding dengan strategi integrated marketing Communication serta memanfaatkan berbagai media komunikasi, promosi serta publikasi secara kontinyu dan terus menerus sebagai upaya untuk membangun city image Jakarta sebagai ibukota multikultural. Multikulturalisme adalah positioning Jakarta. Pengolahan dan penyebaran informasi melalui publikasi dilakukan secara intensif dan masif maka informasi menjadi alat untuk merubah persepsi dan sikap masyarakat (stakeholders). Oleh karena itu, berkaitan dengan strategi city branding Jakarta sebagai Ibukota Multikultural ini, komunikator yang paling memiliki kredibilitas dan signifikan dalam mempersuasi persepsi masyarakat mengenai city image Ibukota adalah Gubernur DKI Jakarta, Anies Baswedan dapat dikatakan sebagai merupakan sumber (source) atau bisa juga dikatakan sebagai figure atau tokoh multikultural yang sangat memberi pengaruh terhadap persepsi masyarakat mengenai 
keberagaman ibukota. Pernyataan- pernyataan Gubernur DKI Jakarta terkait keberagaman budaya di Ibukota dapat dijadikan sebagai informasi dasar untuk mengemas dan mendesain informasi baru dalam format kemasan informasi menjadi positif yang bertujuan untuk mempengaruhi sikap dan kecenderungan perilaku stakeholders. Penyebaran Informasi yang berisi tentang berbagai campaign yang dilakukan oleh Dinparhub DKI Jakarta dalam melakukan berbagai aktivitas city branding selain menjalin kerjasama dengan media konvensional (elektronik dan cetak), juga dengan memanfaatkan secara maksimal berbagai media publikasi yang dimiliki dengan melalukan pengelolaan sebaik-baiknya, dan upgrade informasi secara aktual dan terkini melalui platform media online dan media sosial.

\section{KESIMPULAN DAN SARAN}

Jakarta sebagai Ibukota Indonesia diharapkan menjadi kota modern yang memperlihatkan sisi kultural dengan memberi ruang bagi ekspresi kultural yang menjadi Identitas Kota. Tidak hanya menitikberatkan pada modernisasi fisik, ekonomi dan pemerintahan semata, tetapi juga mengkolaborasikan semua kepentingan tersebut dengan aspek kultural sebagai bentuk sinergitas. Sehingga, diharapkan dapat meminimalisasi berbagai isu yang berkembang di Ibukota baik terkait isu konflik suku, agama, ras dan budaya yang menandakan rendahnya kesadaran akan pentingnya multikulturalisme. City Image Jakarta sebagai 
Ibukota Multikultural merupakan positioning city branding bagi Jakarta yang mampu menciptakan paradigma baru bagi masyarakat Indonesia yang lebih toleran dan elegan dalam merespon berbagai permasalahan sosial budaya yang disebabkan oleh adanya benturan-benturan dari keberagaman budaya atau multikulturalisme. Keberagaman yang ada di Ibukota merupakan sebuah keunikan yang dapat dijadikan sebagai potensi wisata dan budaya bagi Ibukota sehingga dapat meningkatkan perekonomian masyarakat. Peneliti berharap, hasil penelitian ini dapat dijadikan sebagai bahan masukan dan saran untuk meningkatkan lagi kegiatan promosi dan penyebaran informasi pariwisata melalui media massa khususnya elektronik dengan jangkauan siaran yang lebih luas lagi terutama mancanegara melalui strategi komunikasi pemasaran terintegrasi (Integrated Marketing Communication). Selain itu, memaksimalkan sosialisasi dan publikasi tagline "Enjoy Jakarta" serta city image kota Jakarta sebagai Identitas kota yang multikultural. 


\section{DAFTAR PUSTAKA}

Cangara, Hafied. 2014. Perencanaan dan Strategi Komunikasi, Depok: Rajagrafindo Persada.

Gregory, Anne. 2010. Planning and Managing Public Relations

Campaigns: A Strategic Approach. Newyork: Kogan Page Publisher.

Kriyantono, Rahmat. 2014. Teori Public Relations Perspektif Barat dan Lokal; Aplikasi Penelitian dan Praktik, Jakarta: Kencana Prenada Media.

Kotler, P., dan Armstrong, G. 2008. Prinsip-prinsip Pemasaran, Jakarta: Erlangga.

Kotler, P., dan Keller, K.L. 2010. Marketing Management, Jakarta: Indeks Kelompok. Gramedia. 2012.

Mahfud, Choirul. 2011. Pendidikan Multikultural, Yogyakarta: Pustaka Pelajar.

Morissan. 2010. Periklanan: Komunikasi Pemasaran Terpadu, Jakarta: Kencana Prenada Media

---------- Manajemen Public Relations, Jakarta: Kencana Prenada Media, 2014.

Putra, Hendra Setia. 2015. Pengaruh Event Marketing terhadap City Branding Kota Bandung, Bandung: Universitas Pendidikan Indonesia.

Riyadi. 2009. Fenomena City Branding Pada Era Otonomi Daerah. Jurnal Bisnis dan Kewirausahaan, Vol. 5, No. 1.

Rosady, Ruslan. 2018. Manajemen Public Relations dan Media Komunikasi, Depok: Rajagrafindo.

Soebagyo. 2010. Strategi Pengembangan Pariwisata Di Indonesia. Jurnal Liquidity Vol. 1, No.2

Sulaksana, Uyung. 2007. Intergrated Marketing Communication, Yogyakarta: Pustaka Pelajar Offse.

Suprawoto. 2018. Government Public Relations; Perkembangan dan Praktik di Indonesia, Jakarta: Kencana Grenada Media.

Syahputra, Iswandi. 2019. Media Relations; Teori, Strategi, Praktik dan Media Intelejen, Depok: Rajagrafindo Persada.

Terence A. Shimp. 2003. Periklanan Promosi Aspek Tambahan Komunikasi Terpadu.Jakarta: Erlangga

Wasesa, Silih Agung dan Jim Macnamara. 2015. Strategi Public 
Relations, Jakarta: Gramedia Pustaka Utama.

Widiyanto, Chandra Wibowo dan Henilia Yulita. 2015. Pengaruh Pemerekan Kota "Enjoy Jakarta Terhadap Citra Kota, Journal of Business \& Applied Management Vol. 9 No. 2.

Widodo, Bambang dan Mite Setiansah. 2014. Strategi Pencitraan Kota City Branding Berbasis Kearifan Lokal; Studi Kasus Di Kota Solo, Jawa Tengah Dan Kabupaten Badung, Bali, Jurnal Komunikasi Profetik, Vol.7 No.2.

Yeshin, Tony. 2004. Integrated Marketing Communications, The Holistic Approach. Oxford: Elseiver Butterworth Heinemann.

Sumber lain

https://ppid.jakarta.go.id/visi-misi.

http://jakarta-tourism.go.id/2015/jakarta-tourism-culture-office-

jtco? language $=i d$.

https://perempuanOn220185.wordpress.com/2011/12/20/strategicity-branding-kota- jakartal.

https://www.beritasatu.com/megapolitan/522793/pemprov-dkisiapkan-23-festival-di-tahun-2019.

https://megapolitan.kompas.com/read/2019/06/22/22411941/pida to-di-perayaan-hut-dki- anies-sebut-setiap-kebijakannyaprioritaskan.

https://perempuanOn220185.wordpress.com/2011/12/20/strategicity-branding-kota- jakartal

http://www.jurnalkommas.com/docs/jurnal\%20inna.pdf https://www.kajianpustaka.com/2018/11/pengertian-baurandan-strategi-komunikasi- pemasaran.html 